\title{
Analysis of Macro Economic Forecasting Accuracy of South African National Treasury
}

\author{
André Mellet \\ School of Economic Sciences,North-West University, Vanderbijlpark, South Africa \\ Email: andre.mellet@nwu.ac.za
}

\author{
Doi:10.5901/mjss.2014.v5n21p265
}

\begin{abstract}
This research explores the accuracy of economic forecasts by the Ministry of Finance of South Africa. The Ministry of Finance began to implement economic forecasts in 1997 in the time of Minister Trevor Manuel. These forecasts were presented every year since 1997 in the annual budget speech. The Minister of Finance (Pravin Gordhan) who succeeded Minister Manuel continued to deliver economic forecasts in the annual budget speech since 2010. The research focused on the period 1997 2009 when Minister Manuel was the ruling political leader of National Treasury, although data for 2010 and beyond is included. A mixed-methods approach was followed to compare the annual forecasts with the actual and official statistics presented by the South African Reserve Bank and the Department of Statistics. Economic forecasts are important for the business sector, the financial sector and the government sector. These forecasts about economic indicators are used by the fiscal authority to provide information regarding the possible outcome of output, revenue and debt for the new budget year. These forecasts can also be used by various institutions for budget purposes, draft of financial contracts and planning of capital projects. Not all institutions can afford to manage a highly technical business unit that delivers economic forecasts run by various mathematical models and post graduate economic employees. The research demonstrated that the Ministerial forecasts for real growth and inflation can be used successfully.
\end{abstract}

Keywords: Ministry of Finance; forecasting; economic growth; inflation rate; balance of payments

\section{Introduction}

In the annual budget speech delivered in 1997, Minister Manual began to make one year forecasts regarding certain macro economic indicators. This research investigates the forecast accuracy of the National Treasury's team of economists during the period of Minister Manual as Minister of Finance. This research covers the period from 1997 to 2009 when Minister Manuel was the ruling Minister of Finance. The focus will be on three important indicators, namely economic growth, inflation and the current account balance. The outcome of this research proves if the business sector, banks and all other interested institutions about economics can rely on these annual budget forecasts. This study proves that the forecasts are fairly accurate, therefore, the annual forecasts of the National Treasury team can be used in the draft of budgets and strategic planning of numerous institutions.

The forecasts of the Minister will be compared for each year with the actual figures released by the South African Reserve Bank and the Department of Statistics. Interviews were conducted with members of the budget division to enquire about the different models and techniques used in forecasting the economic parameters each year. A new Minister of Finance was appointed by the new president after the 2009 political elections. Regardless of the man in power, there is a team of economists and mathematicians in the department of National Treasury that do the annual research. Forecasts of the new Minister are also summarized and displayed in the addendum. Accuracy and reliability of these forecasts can thus also be interpreted for the period after Minister Manuel.

Although Minister Manuel experienced the effects of poverty when he grew up in the Cape Flats, he studied at the Peninsula Technikon (Green, 2008). Minister Manuel developed as a political leader with remarkable intellect and leadership qualities. Minister Trevor Manuel served as South Africa's Minister of Finance since 1997. Minister Manuel changed position in 2009 and became Minister of Planning in the office of the President. According to Cameron (2006) Minister Manuel is regarded as an excellent minister for various reasons, for example that he reduced the level of government debt to within the international norm of $2 \%-3 \%$ of gross domestic product. He served in senior positions on various international bodies such as the International Monetary Fund, the World Bank and the United Nations. He also represented South Africa at the G20 nations.

Economists differ about the actual causes and the nature of fluctuations in the economy. The reason being that there are many variables (local and international) that determine the outcome of the South African economy. According to 
Dornbusch and Fisher (1987) the process of forecasting is very complex but it is necessary for government and all businesses. National Treasury as government authority that employs fiscal policy needs to predict economic indicators to provide information to compute the possible outcome of output and revenue. If a company is a big lender or a big borrower, it is important to know what should happen to the inflation rate because as the inflation rate changes, so will interest rates which are directly correlated. According to Wright \& Goodwin (1986) economic predictions are also very difficult in comparison to explain events that occurred in the past which are facts and undisputable. The latter is easy, because there is normally a cause, passage and a result.

There are various examples to consider when economies world wide did not move in the traditional cycles of upswings and down-swings. An unexpected change in the exogenous oil price increase in the early 1970s is a prime example (Burda \& Wyplosz, 2009). The American automobile firms were not able in the early 1970s to foresee the changes in consumer attitudes towards smaller and more oil efficient cars. This mistake gave opportunity to West European and Japanese automobile firms to move into this niche. Another example was the Asian Tiger's crisis of 1997/8 when East Asian countries developed cash flow problems which caused interest rates to increase in all emerging markets to protect their balance of payments. A last example is the recent USA banking crisis of 2007 which caused the world to turn into a recession with millions of job losses (Burda \& Wyplosz, 2009).

According to the above examples all businesses must be enlightened of what is expected in the field of economics for the following year(s). Forecasting is a science and an art and most businesses do not possess the infrastructure and money to do their own forecasting. This study should be handy for all South African corporate entities, banks and small businesses to use the National Treasury team's annual forecast as a source to complete budget processes.

This research will, firstly, define economic terminology to clarify what the budget process and various indicators are all about. Secondly, the process of forecasting are discussed to explain the complexity to read the future. Thirdly, the three indicators will be analyzed for the period when Minister Manuel was in power to draw conclusions if the forecasts are in fact useful in management processes in South Africa. Lastly, a brief discussion of the three indicators for each year gives a background of the ruling economic environment to explain why the indicators some years increased and some years decreased.

\section{Economic Terminology}

The forecasts for each year were obtained from the budget review of the specific year as tabled by the Minister in parliament in February each year. The data used to compare these different forecasts to determine the Minister's accuracy, was obtained from the Quarterly Bulletins of the South African Reserve Bank (SARB). According to Mohr (2000) preliminary estimates are released as soon as possible, but these data are subject on a continuous basis to revisions as new and better information become available as well as the data methods and techniques that improve. The most recent available data were used for each year following the prediction for comparison purposes. The comparison will be followed by a short discussion of relevant occurrences that took place during a specific year which might have had an impact on any of these three indicators.

\subsection{Growth}

Before the different methods of forecasting are addressed, the terminology of certain economic notions is explained, for example economic growth. This is probably the most important economic goal. Economic growth measures the sustained increase in production of goods and services in a specific period relative to a previous period (Fourie \& Burger, 2010). The gross domestic product (GDP) is used to do the percentual calculation and there are four important elements to consider (Mohr, 2008). The first element is value, namely which products, how many products and at what price. The second element is final, namely only products that are used in the final instance by consumers and not intermediate products which are used in the production of products. This is important to avoid double counting. The third element is about the geographic area that is covered and the last element is about the period. The GDP is calculated on a quarterly basis and when the fourth quarter's figures are added, the annual GDP is then available.

As this calculation is done on a quarterly basis, this increase or decrease can be compared to the change in the population of a country to see if there are in fact an increase or decrease in living standards and any creation of job opportunities or not. To do these comparisons the prices of a specific period are used to determine the value. However, these values are inflated. The GDP at current or nominal prices includes inflation. The GDP at constant or real prices are used in this research which excludes inflation (Janse van Rensburg et al., 2011). The real GDP of a country is also a useful tool in any comparisons with other countries. If any comparison between economic aggregates is done, for 
example the Rand value of the South African government debt to the Dollar value of the USA government debt, the specific figures can be expressed as a percentage to the real GDP of the country and then an effective comparison can be done.

\subsection{Inflation}

Inflation is about the price stability in a country. This price stability is also an important goal of any government because it affects the cost of living and living standards of its inhabitants. According to Mohr (2008) the inflation of a country is a continuous and considerable increase in prices in the general price level of goods and services. To calculate the inflation rate, an index must be used (Fourie \& Burger, 2010). The consumer price index (CPI) measures for example a representative basket of consumer goods and services. There are various other indices, for example the production index which measures the production cost at factories or imported goods.

The South African Reserve Bank used the CPIX index in their monetary policy and inflation targeting. This index is the CPI excluding interest rates on mortgage bonds. In this research the CPIX is used since its inception until 2008. SARB in collaboration with the Department of Statistics developed a new and updated CPI and began to use this index since the beginning of 2009. Since the beginning of 2009 the CPIX is not calculated any more and the new CPI is used in this research.

\subsection{Current Account}

According to Dornbusch et al. (2004) the current account of the balance of payments of a country is the record of all trade in goods and services, as well as transfer and income payments amongst countries. The current account shows the inflow and outflow of Rand resulting from trade amongst South Africa and other countries as well as transfers and income flows for example remuneration of workers that work in other countries and dividend payments on investments. These movements of capital across borders influence the foreign reserves of South Africa which is important to repay foreign debt and to finance imports (Fourie \& Burger, 2010).

The stability of the current account is very important for any country and has a major impact on the exchange rate of the Rand relative to the USA $\$$ or the Euro. If the current account is negative like in South Africa since 2003, it means that the government and corporate institutions must attract foreign investments or loans (SARB, 2009). These foreign investments are recorded in the financial account of the balance of payments. A stable current account is necessary in South Africa to avoid a depreciation of the currency. If not, South Africa needs new foreign investments every year to avoid depreciation. Other determinants of exchange rates are price level differences between countries, interest rate differentials, changes in consumer preferences for products of foreign countries, changes in capital flows and speculation (Janse van Rensburg et al., 2011). If a volatile or depreciating scenario exists, it makes the financial management of importers and exporters very difficult which can increase the prices of goods and ultimately inflation if the trend of the exchange rate is forecasted incorrect.

\subsection{Fiscal policy}

According to Smit et al. (1997) the Minister of Finance is the political and policy head of the fiscus. Government intervention in the economy focuses on one overall objective, namely to create the maximum economic welfare for all its inhabitants. The fiscal policy objective and measures are included in the annual budget presented to Parliament in February each year by the Minister of Finance. The highest legislative authority in the South Africa, namely parliament, accepts responsibility for the fiscal policy administered by the National Treasury Department.

Fiscal policy consists of three elements, namely government expenditure, taxes and loans (Fourie \& Burger, 2010). The main instrument is the budget which is the vehicle to change any of these elements to ultimately change the spending behavior of the country's inhabitants and thus welfare. The budget, as read by the Minister of Finance every year in February, is therefore a very powerful economic and political instrument in the hands of the ruling political party. If the cabinet decided to expand the economy and to create more job opportunities, an expansionist budget is prepared to increase the spending and income of all the inhabitants (Janse van Rensburg et al., 2011). An expansionist fiscal policy influences interest rates and the money supply of South Africa (Black et al., 1997). If cabinet decided to control the spending and demand inflation in the country, a contractionary budget is prepared to reduce the spending of all the inhabitants and therefore also the real growth rate.

The budget speech of the Minister of Finance is one of the most important speeches in Parliament every year 
because it influences future economic growth (Black et al., 1997). This speech creates market responses because it influences investment expenditure and the spending behavior of all the inhabitants of South Africa for the next twelve months. This speech is debated in the country in all possible means, for example the press, the radio, television and the social network. It is therefore important for industry and all stake holders to listen to the Minister of Finance every February to manage their businesses and change their budgets for the period to come regarding fiscal policy changes as announced. The Minister's forecasts regarding economic indicators are thus a useful tool to incorporate in financial planning and budgets. Before the forecasts of National Treasury are evaluated, forecasting will be analyzed to get an understanding of this complex economic process to read the future.

\section{Forecasting}

\subsection{What is forecasting?}

A forecast is any statement about the future. Statements may be well founded with a sound basis, it may be accurate or inaccurate and may be model based or informal (Clements, 2002). Economic forecasting is defined by Carnot (2005) as a set of hypothetical statements about future macroeconomic developments. It is a structured way to look into the future by means of the interpretation of available data at a point in time. Economic expertise and knowledge of several techniques is required to make well founded forecasts. Historical trends and the forecaster's judgment also play an important role.

Economic relationships and economic models also play a role. A forecaster cannot make any forecast regarding economic events if positive and negative relations as well as principles of macroeconomics are not understood. It is also important to measure the probable impact of the appropriate indicators in order to make the forecast meaningful (Butler, 1974).

Many critics against scientific forecasting are from the opinion that forecasting is an art and not a science. The art of forecasting will always depend on the practitioner's intuition and good judgment. Butler (1974) agrees with this statement but also adds that no good art is without structure. Any good forecaster has to have good knowledge of the technical aspects of forecasting and should also have experience in the specific field of forecasting. Many tools, techniques and computer models are available to be used by a forecaster. In economic forecasting, no matter what variables are being forecasted, a well-founded forecast normally depends on some underlying econometric model. Therefore, economic forecasting includes the application of macroeconomic theory, the use of an econometric model and an element of art or intuition. It is thus not an exact science.

\subsection{Is there a need for forecasting?}

According to Clements (2002) anything can be forecasted, since it is merely a statement about the future. However, not all forecasts are useful. Carnot (2005) lists the main variables that economists use in their modelling and forecasting of the future. This include output of a country, the inflation rate, unemployment, interest rates, exchange rates, international trade flows, fiscal balances and public debt. Minister Manual did selective forecasts every year in his budget speech and three common indicators were used in this research.

The scientific objective of the first forecasting models, which materialized in the 1930s and 1940s was to test the empirical relevance of economic theories using statistical data that became available from the national accounts systems all over the world. In later years forecasts served more needs than only testing theories. Forecasts today are indispensable to reach practical objectives in management as well as budgeting processes of companies.

The only factor that all forecasts have in common according to critics is that all forecasts are wrong. According to Lanchester and Lomas (1985) perfection is unattainable. The criticism against forecasting errors depends on how big the deviation eventually is. If forecasts are scientifically done, it assists all users who do not have the skills, time or capital to do it themselves. According to Carnot (2005) forecasts need to be done to assist management of businesses to make educated decisions in their budget processes. Forecasting assists governments in their application of policies, for example when must they apply brakes to reduce economic activity or when must they apply petrol to increase consumer and corporate spending. The forecasts of Minister Manuel are useful for the business sector but are also used in application of policies, for example fiscal policy.

\subsection{The time horizon and process of forecasting}

The time horizon refers to the period of time into the future for which forecasts are required (Levenbach \& Clearly, 1984). 
Four periods can be distinguished, namely the immediate term (current to two quarters ahead) and the short term (six months to two years). The next period is the medium term (two to five years) and lastly the long term (longer than five years).

The forecasting process consists of several steps. If a forecast is done, it begins with a decision making process, namely that the objectives and applications of the forecast are clearly specified. After the objectives and variables are specified, the time dimension must be agreed on. The next step is to gather the data (quantity and quality) from internal and external sources.

The next two steps involve the selection and evaluation of the forecast technique(s). According to Wilson \& Keating (1994) several criteria effect this decision, namely the availability of the data, the forecast horizon, the quantitative background of the forecaster and the urgency of the forecast. If the most appropriate forecasting method is selected, the forecast is done and presented. The last step is to track the results as the actual data becomes available. The purpose of this research is to track the results of three economic indicators forecasted by Minister Manual in his annual budget speeches.

\subsection{Choosing the most appropriate forecasting method}

\subsubsection{Judgmental forecasting}

The most common of all forecasting methods is judgmental forecasting. Judgmental methods vary extensively from one another. This method can range from pure guess work to fairly systematic approaches that make use of the same underlying theoretical framework of macroeconomics that is used in the scientific approaches (Butler, 1974). If a forecast is derived from a judgmental approach it can rarely be replicated by another forecaster because of individual preferences and bias. The importance of a unique forecasting strategy can be emphasized because of personal judgmental inputs and experience. It can therefore not be used by a large number of users and copied in any way by other forecasters as their forecast.

Judgmental approaches have been very successful in economic forecasting. Social scientists are concerned with facets of human behaviour which is difficult to describe with precision. The rule of thumb tactic is seldom used in forecasting in any kind of social science (Young, 1968). Therefore, any static set of mathematical relations with precise parameter values determined from historical data has an inherent disadvantage in forecasting future events. Judgmental forecasting allows the forecaster to adjust to changing circumstances (Butler, 1974).

Judgment is also emphasized by (Butler, 1974) to be dependant of underlying knowledge. In economic forecasting, the judgmental approach relies as much on macroeconomic theory as econometric models. If the judgmental method is used, the forecaster can change the weights attached to different variables on a continuous basis based on his or her intuition. This flexibility is one of the important contributions why judgmental forecasting renders good results on a continuous basis if compared to econometric forecasting.

\subsubsection{Scientific forecasting}

Armstrong (1985) calls scientific methods of forecasting explicit and formal. Models of forecasting are normally so explicit that any forecaster that uses an identical set of assumptions will generate the exact same forecast. Specific and logical laid out steps are used that begin at the assumptions to produce the actual forecast itself. The process is done with the aid of a computer model.

There are various scientific techniques that can be used to manipulate data for example input-output models and extrapolation. Statistical methods are reliable and if the same data is used, the same forecast will be generated every time. These approaches are easier to interpret and analyse than judgmental forecasting techniques. Two most common methods of the numerous scientific approaches will be discussed briefly.

Firstly, time series is used. In extrapolation, it is assumed that the future will differ from the present in the same way as the present differs from the past (Young, 1968). The biggest problem with these methods is that a statistical view is used which leaves limited room for economic analysis. Time series analysis gives the best results in the very short term. Methods that are used can range from simple univariate forecasting to multivariate forecasting that is very complicated.

According to Armstrong (1985) one of the most popular methods of time series analysis is the Box-Jenkins approach. Despite its popularity, it is very complicated and very expensive to apply. The Box-Jenkins method uses the most up to date observation as the initial values and then examines the recent forecasting errors to determine the 
appropriate adjustments for future time periods. Other methods such as the naïve extrapolation and exponential smoothing techniques are much more simplistic.

Secondly, econometric models are used. Econometrics is formed from two Greek words, economy and measure. It is therefore the measurement of economic relationships. According to Koutsiyiannis (1977) it is the combination of economic theory, mathematical economics and statistics. If these three fields of study are integrated, it provides numerical values for the parameters of economic relationships amongst various parameters and it also verifies economic theories at the same time.

Econometric forecasting relies on the causal interpretation of the underlying economic model. This approach has various objectives, one of which is to forecast values of different economic parameters. According to Kennedy (1985) these models can be used to forecast the dependent variable if the related values of the independent variables are known. Econometric models can range from relatively basic approaches such as linear regression models to very complicated simultaneous-equation models.

\subsubsection{Combined techniques}

Composite forecasting techniques are created by combining alternative forecasting methods. The objective of these approaches is to take advantage of the strengths of each different method to obtain a forecast. According to Armstrong (1998) judgment and statistical methods should be integrated in time-series forecasting. The judgment of the forecaster is useful in time-series research because the knowledge of events that occurred in the past can be incorporated. It is also useful to analyze the impact of events expected to occur in the future that have not occurred in the past. Another benefit of combining judgment and scientific approaches is that an unaided judgment approach can be biased when the forecaster reads more in the data that is warranted. Other combinations are also possible, for example the Box-Jenkins method and exponential smoothing. These composite forecasting methods tend to render smaller errors than those of individual forecasts.

\subsection{Forecasting accuracy}

To make accurate economic forecasts is impossible because of all the variables that are involved. South Africa is an open economy, therefore not only local economic variables and politics influence the process of forecasting, but also foreign policies and capital flows. Accuracy should not be confused with certainty (Carnot, 2005). An accurate forecast therefore simply means that the risk of error is limited.

Several factors must be taken into consideration when the accuracy of forecasts is evaluated (Zarnowitz, 1974). Firstly, a single success or failure does not prove the forecasts to be accurate or not accurate. The average performance of a forecaster has to be studied to make any proper conclusion. Secondly, the conditions and the type of economic changes that took place during the period have to be taken into account. Some conditions are more difficult to forecast than others. Thirdly, the range of the forecast undertaken has a large effect on the magnitude of the forecasting error. As the period gets longer, the probability for an error increases. Lastly, it is important to distinguish between forecasting errors and measuring errors. The fact that most data is revised frequently, points to the fact that data are subject to large errors.

Various measures can be used to compare different models or the accuracy of forecasts with each other. According to Koutsoyiannis (1977) a method can be used to compare the accuracy of forecasts, namely the predictionrealization diagram. The predicted values, $\mathrm{Pi}$ are plotted on the $\mathrm{x}$-axis while the actual values, $\mathrm{A}_{i}$ are plotted on the $y$-axis. Points laying in quadrant ii and iv indicate that the directions of changes in the variable were forecasted correctly. Points in quadrant $\mathrm{i}$ and iii show the opposite, namely that a turning point error was made.

A $45^{\circ}$ line with a positive slope through the origin of the graph can be introduced. This line is called the line of perfect forecast. Any point on the line shows that there is no difference between the forecasted value and the actual value. Therefore, the closer the forecasts are to this line, the more accurate is the forecast (Koutsoyiannis, 1977).

\section{Evaluation of Minister Manuel's Forecasts}

Forecasting in the government tends to focus more on the short term. The methods used include almost all the approaches as discussed earlier. In addition to the judgmental forecasting other methods are used, for example leading indicators, surveys and trend extension cyclical patterns. The Department of National Treasury also makes use of additional sources such as research done by universities (Passer, 1974). Forecasting by National Treasury is necessary 
and important because government has policy targets to meet and economic indicators have to be predicted to provide information regarding the possible outcome of output, revenue and debt (Dornbusch et al., 2004).

\subsection{Economic growth}

Table 1: Actual versus forecasted Gross Domestic Product (GDP)

\begin{tabular}{|c|c|c|}
\hline YEAR / INDICATOR & FORECASTED GDP & ACTUAL GDP \\
\hline 1997 & 2.0 & 1.5 \\
\hline 1998 & 3.0 & 0.0 \\
\hline 1999 & 0.9 & 1.2 \\
\hline 2000 & 3.5 & 3.1 \\
\hline 2001 & 3.5 & 2.0 \\
\hline 2002 & 2.3 & 3.0 \\
\hline 2003 & 3.3 & 2.0 \\
\hline 2004 & 2.9 & 3.5 \\
\hline 2005 & 4.3 & 5.0 \\
\hline 2006 & 4.9 & 5.0 \\
\hline 2007 & 4.8 & 5.1 \\
\hline 2008 & 4.0 & 3.1 \\
\hline 2009 & 1.2 & -1.8 \\
\hline
\end{tabular}

Source: SARB (1998 - 2010) \& Manual (1997 - 2009)

Figure 1: Actual versus forecasted GDP

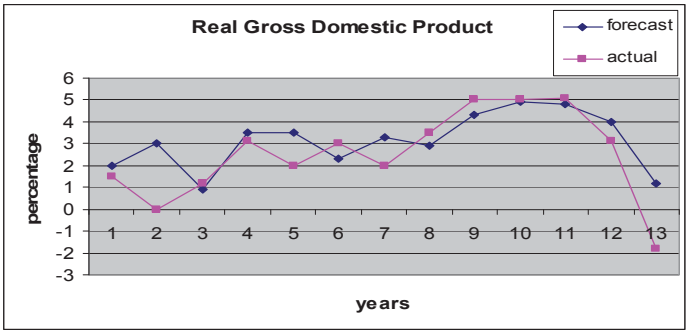

Figure 2: Prediction Realisation of GDP

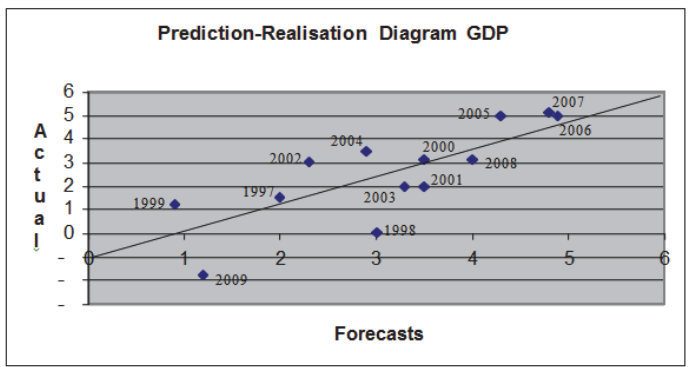

All the points are laying in quadrant ii which indicates that the directions of changes in the GDP variable were forecasted correctly. The biggest error can be observed for 1998 and 2009. The SARB took firm policy measures to defend the Rand during the Asian crisis of 1998. This emerging country's crisis caused a dramatic fall in business and consumer confidence in South Africa. During 2009 South Africa experienced a recession caused by the sub-prime international financial crisis. National Treasury applied proper counter cyclical fiscal policy to mitigate the negative impact of the biggest recession since the great depression of the 1930s. 


\subsection{Inflation}

Table 2: Actual versus forecasted Inflation

\begin{tabular}{|c|c|c|}
\hline YEAR / INDICATOR & FORECASTED INFLATION & ACTUAL INFLATION \\
\hline 1998 & $5.5 \mathrm{CPI}$ & 6.9 \\
\hline 1999 & $6.1 \mathrm{CPI}$ & 5.2 \\
\hline 2000 & $6.8 \mathrm{CPIX}$ & 7.8 \\
\hline 2001 & $6.6 \mathrm{CPIX}$ & 6.6 \\
\hline 2002 & $6.9 \mathrm{CPIX}$ & 9.3 \\
\hline 2003 & $7.7 \mathrm{CPIX}$ & 6.8 \\
\hline 2004 & $4.8 \mathrm{CPIX}$ & 4.3 \\
\hline 2005 & $4.0 \mathrm{CPIX}$ & 3.9 \\
\hline 2006 & $4.3 \mathrm{CPIX}$ & 4.6 \\
\hline 2007 & $5.1 \mathrm{CPIX}$ & 6.5 \\
\hline 2008 & $7.1 \mathrm{CPIX}$ & 11.5 \\
\hline 2009 & $5.8 \mathrm{CPI}$ & 7.1 \\
\hline
\end{tabular}

Source: SARB (1998 - 2010) \& Manual (1997 - 2009)

Figure 3: Actual versus forecasted Inflation

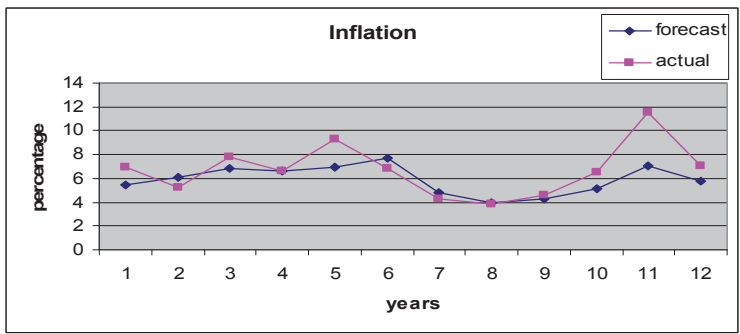

Figure 4: Prediction Realisation of Inflation

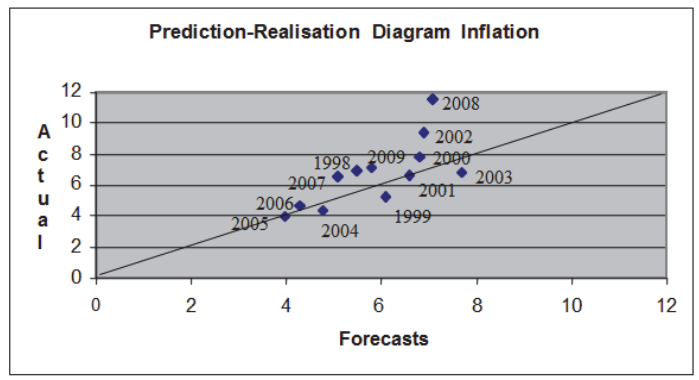

All the points are laying in quadrant ii which indicates that the directions of changes in the inflation variable were forecasted correctly. Two errors can be observed. The forecast for 2002 was to low. The main reason for the very high inflation in 2002 was the sharp depreciation of the Rand since the last months of 2001. SARB changed their foreign exchange policy and the prices of food, transport and health all increased. The second error was for 2008 when the forecast was conservative again. The main reason for the high inflation was the big increases in the prices of commodities in the world as well as the international oil price and food. This can be attributed to the China-effect, namely the continuous strong growth experienced for a couple of years from the Far-East that created shortages of commodities and food. 


\subsection{Current account balance}

Table 3: Actual versus forecasted Current account balance

\begin{tabular}{|c|c|c|}
\hline YEAR / INDICATOR & FORECASTED CURRENT ACCOUNT & ACTUAL CURRENT ACCOUNT \\
\hline 1998 & $-1.5 /-2.0$ & -2.1 \\
\hline 1999 & -1.0 & -0.4 \\
\hline 2000 & -1.0 & -0.3 \\
\hline 2001 & -1.1 & -0.2 \\
\hline 2002 & -0.5 & +0.3 \\
\hline 2003 & -0.5 & -0.8 \\
\hline 2004 & -1.3 & -3.2 \\
\hline 2005 & -3.1 & -4.2 \\
\hline 2006 & -4.4 & -6.4 \\
\hline 2007 & -5.3 & -7.3 \\
\hline 2008 & -7.3 & -7.4 \\
\hline 2009 & -6.3 & -4.0 \\
\hline
\end{tabular}

Source: SARB (1998 - 2010) \& Manual (1997 - 2009)

Figure 5: Actual versus forecasted Current account balance

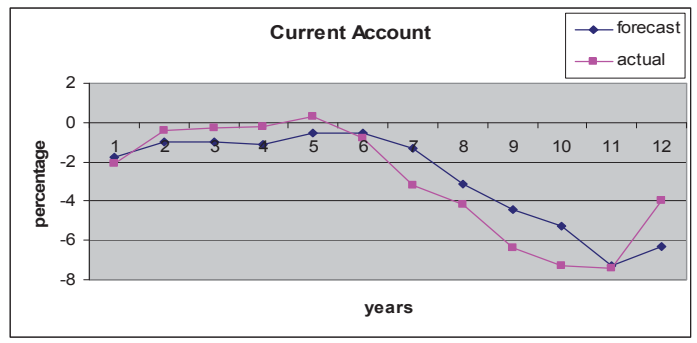

Figure 6: Prediction Realisation of Current account balance

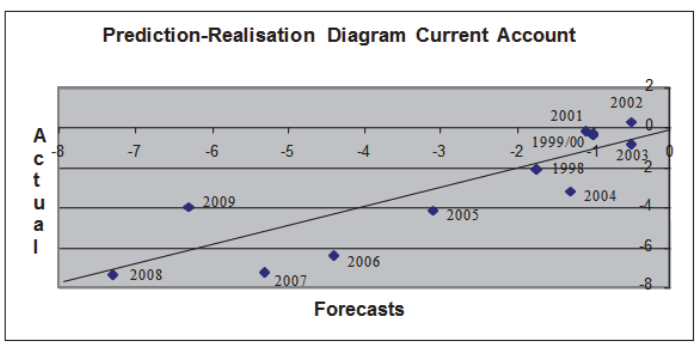

All the points are laying in quadrant ii except for 2002, which indicates that the directions of changes in the current account variable were forecasted almost correctly. Errors or rather conservative forecasts are observed for the years 2004 - 2007. This economic variable was the least accurate forecasted by the Department of Finance. The reason being that fiscal policy (of which the Minister of Finance is the political head) influences the growth rate of South Africa every year. Monetary policy is closely related to fiscal policy (fiscal policy set the inflation target and the Minister of Finance and governor liaise about policy on a continuous basis) and the Minister should therefore have a strong feeling for any inflation developments and appropriate policy.

The Minister of Finance however does not have that close knowledge of developments that influence the balance of payments. Lots of variables that bear an impact on the current account are influenced by foreign countries of which his control and influence are limited. It is clear from the GDP data that South Africa experienced accelerated growth rates 
since 2004 which indicated that the world growth accelerated as well. South Africa experienced a strong growth period on the Johannesburg Stock Exchange against the background of booming international commodity prices. The record investments on the South African stock exchange brought billions of foreign capital into South Africa which caused tremendous outflows of dividends the next year on the current account. The surge in development of the Far East also caused a tremendous impact - South African exports of raw materials increased, whilst South Africa imported more and cheaper manufactured goods than could be produced locally. His conservative forecasts for these few years were correctly adjusted in 2008. The big difference in 2009 is again because of the recession caused by the sub-prime international financial crisis.

\subsection{Economic developments}

A brief discussion of the three indicators used in the annual forecast gives a background of the economic environment for specific years. This brief summary for each year explains why local or foreign developments influenced the three indicators in some years to increase and in some years to decrease.

\subsubsection{Economic developments 1997 (SARB, 1998)}

Growth: Minister Manuel tabled his first budget in 1997 and made only one forecast regarding economic indicators. The real economic activity declined in 1997, reflecting weaker growth in aggregate domestic demand. The GDP increased by more than $3 \%$ in 1996, but decreased to a positive figure of only $1,5 \%$ in 1997 . This slowdown in activity occurred in the second half of 1997. The manufacturing production and real output of the commercial sector were primarily responsible for this slowdown of economic growth.

The first 'Medium Term Budget Policy Statement' was released on 2 December 1997. This policy document of Minister Manuel was an expenditure and revenue plan for the next three fiscal years. The key element of this policy document initiated a process of three-year rolling budgets. The purpose was that government departments should frame their policy proposals within their three-year budgetary allocations. These budgets should be in line to targets indicated by the Macroeconomic Strategy for Growth, Employment and Redistribution policy (GEAR).

\subsubsection{Economic developments 1998 (SARB, 1999)}

Growth: Minister Manuel tabled his second budget in 1998 and made forecasts regarding all three economic indicators. The real economic activity slowed down mainly because of the contagion from the Asian countries. The negative affect occurred through three channels. Firstly, less investment in South Africa because of a higher risk premium towards emerging countries. Secondly, the Asian counties' currencies depreciated which made their exports more competitive. Thirdly, their imports declined because of their economic slowdown.

Inflation: the price of imported goods rose sharply in the middle quarters of the year and interest rates increased substantially which caused the cost of living to surge. Interest rates began to decrease late in the year when the international markets began to stabilize.

Current account: the deficit on the current account was financed through inflows of portfolio capital. This volatile type of capital made South Africa vulnerable to the Asian flue. Weak demand for exports in the second half of 1998 and a sharp rise in imported capital goods worsened the deficit.

\subsubsection{Economic developments 1999 (SARB, 2000)}

Growth: the real economic activity recovered in 1999, reflecting the improvement in global economic conditions after the Asian flue of 1997 and 1998. The Asian flue impact in the international economy worsened when the Russian Federation unilaterally restructured its Rouble-denominated debt in August 1998, which prompted a number of central banks in the world to lower official interest rates to stabilize financial markets. Despite these troublesome events the South African economy began to improve. The recovery occurred since the second half especially in the agricultural sector and the tertiary sectors.

Inflation: production prices rose sharply. This increase was mainly because of the rise in the international crude oil price. The year-on-year inflation in the prices of domestically produced goods rose for example from $4,0 \%$ in January 1999 to $6,5 \%$ in January 2000. The year-on-year change in the prices of imported goods rose to $13,1 \%$ in January 2000 - the highest rate since February 1991 mainly influenced by the higher oil price. 
Current account: largely because of a strong improvement in the trade balance, the deficit on the current account declined considerably from R11,6 billion in 1998 to R2,9 billion in 1999. The quarterly estimates of the balance-ofpayments figures however began to deteriorate because of the recovery in the South African economy. This was reflected in increases of the value of merchandise imports.

\subsubsection{Economic developments 2000 (SARB, 2001)}

Growth: the real economic activity improved relative to the previous year, mainly because of an improvement in the secondary sector. Manufacturing output increased because of greater competitiveness of domestic firms following the weaker Rand exchange. Agricultural output however decreased in the last quarter of the year.

Inflation: production prices continued to rise sharply and reached $9,2 \%$ in 2000 , the highest rate in five years. CPIX inflation also continued to increase in the first half of the year, but began to decrease in the second half of the year. The long established relationship between the PPI and CPI indices were broken in the second half of the year. The PPI index leading the movements of the CPI indices was challenged and could not be used any more as an early indication of potential price movements.

Current account: the current account was in deficit for almost the whole year, but improved in the fourth quarter to a surplus mainly because of a substantial increase in merchandise exports. Various sectors benefited from this increased demand of exports, mainly the mining and manufacturing sectors

\subsubsection{Economic developments 2001 (SARB, 2002)}

Growth: the real economic activity was influenced by the deterioration of the global economy. The terrorist attacks on America caused a chain reaction of economic events across the global economy. These attacks pushed America into a recession and dragged economic activity down on a global basis because of weaker demand.

Inflation: the Rand depreciated substantially in the latter part of the year because of policy changes at SARB. The inflation indices declined in the first half of the year, but increased substantially in the latter part of the year because of the massive depreciation of the Rand.

Current account: the value of merchandise exports increased by $20,3 \%$ for the year, whilst the value of imports increased by $16 \%$ for the same time. The deficit on the current account was fairly unchanged relative to the previous year, but the financial account changed into a deficit for the fourth quarter because exporters accumulated offshore assets to profit from the depreciation of the Rand. These activities worsened the depreciation of the Rand and thus the negative impact on inflation for times to come.

\subsubsection{Economic developments 2002 (SARB, 2003)}

Growth: the real economic activity performed impressively as reflected in the duration of the upward movement of the business cycle. This expansion to date was the fourth longest on record since the Post World War II period which began in September 1999 and was in progress for 40 months. The pace of growth began to slow in the second half of 2002 due to declining activities in the secondary sectors and the primary sectors of the economy.

Inflation: production price inflation increased strongly following the depreciation of the exchange rate of the Rand. Food prices and energy costs also pushed prices higher. Consumer inflation accelerated sharply in 2002, mainly because of the sharp depreciation of Rand. The exchange value of the Rand recovered appreciably in 2002 from the setbacks suffered in 2001 and this appreciation helped to reduce the cost of imported goods during the year.

Current account: the improvement in the current-account balance in 2002 occurred mainly in the first half of the year. Merchandise exports and net gold exports rose sharply, but these exports leveled off in the second half of 2002 because of weaker international demand for domestically produced goods. Merchandise imports began to increase in the second half of the year because of an increase in gross domestic expenditure.

\subsubsection{Economic developments 2003 (SARB, 2004)}

Growth: the real economic activity improved in the third and fourth quarters of 2003. This improvement was against the background of the world economic recovery that gained momentum in the second half of 2003. This recovery could mainly be contributed to the improvement in the agricultural and manufacturing sectors.

Inflation: the rand continued to appreciate substantially. This appreciation was also supported by lower food and a 
lower oil price. The cost of domestically produced goods declined to $3,9 \%$ from $13,5 \%$ in 2002 , whilst the cost of imported goods declined to minus 4,2\% from and increase of $15,5 \%$ in 2002.

Current account: the current account surplus of the previous year turned into a deficit in 2003. The improvement of the global economic environment should have benefited South African exports, but the continuous appreciation of the Rand diluted our export values. The increase in the quantities of imported goods, because of an increase in domestic expenditure, also contributed to the growing deficit. The trade balance declined substantially in the fourth quarter because of these developments.

\subsubsection{Economic developments 2004 (SARB, 2005)}

Growth: real economic activity improved in 2004, mainly because of an increase in real domestic final demand. The improved growth was mostly evident in the two middle quarters of 2004. The weaker growth in the fourth quarter was mainly because of a slowdown in the mining and manufacturing sectors.

Inflation: the external value of the Rand continued to appreciate, interest rates declined and a decrease in international food prizes were the main factors that caused a decline in inflation. The appreciation of the Rand continued to influence the prizes of imported goods positively.

Current account: against the background of an improved performance in economic activity, South Africa's trade balance with the rest of the world began to deteriorate. The deficit on the current account widened accordingly to more than the international norm of $-3 \%$. The strengthening of the exchange rate as well as strong domestic demand caused the physical quantity of imported goods to rise and the deficit rose strongly in the fourth quarter.

\subsubsection{Economic developments 2005 (SARB, 2006)}

Growth: real economic activity improved in 2005 to 5\%, the highest since 1984. The economic growth lost some momentum in the second half of 2005, mainly because of a decline in the primary sector and slower growth in the secondary sector. Aggregate real gross domestic expenditure increased by $6 \%$ in 2005 relative to $7,5 \%$ the previous year.

Inflation: for 2005 CPIX inflation remained mostly below the midpoint of the inflation target range of $3 \%-6 \%$. The appreciation of the rand in the second half of the year as well as relatively small increases in food prices, helped to contain inflation. The year-on-year PPI inflation of domestically produced goods increased steeply in the second half of the year.

Current account: the global economy continued to expand briskly. The sustained high international oil price (reaching US $\$ 70$ per barrel at end of August) and global current account imbalances were increased risk factors for sustained growth at high real rates. Most countries in the world began to apply restrictive monetary policies since mid2005. Imports and exports began to decline in the last quarter. South African export volumes for the year however increased by $8,5 \%$ consistent with the strength of the global economy.

\subsubsection{Economic developments 2006 (SARB, 2007)}

Growth: the real economic activity continued to be healthy 2006. The growth of the mining sector accelerated because of a strong increase by platinum and diamond mining. Platinum mining benefited from strong demand in the jewelry and industrial sectors. The sustained increases in value added by the manufacturing sector reflected a continued high level of business confidence and strong domestic demand. Production capacity in manufacturing recorded a record high of $86,6 \%$ in the final quarter of 2006.

Inflation: CPIX inflation accelerated considerably during the middle quarters of 2006. This increase was due to accelerating food prices at agricultural and manufactured levels, rising service prices and also an increase in the international oil price. The CPIX inflation broke out of the $3 \%-6 \%$ target range for the first time since the beginning of 2003.

Current account: the South African economy experienced an upward phase of the business cycle since 1999 and the gross domestic expenditure has consistently exceeded national disposable income since 2003. This healthy domestic demand and the simultaneous strong demand for crude oil and capital equipment resulted in a substantial increase in the current account deficit. 


\subsubsection{Economic developments 2007 (SARB, 2008)}

Growth: real economic activity continued to expand. Growth accelerated in the secondary sector, while growth in the primary and tertiary sectors declined. Growth in the trade sector declined substantially relative to the previous year. Higher interest rates and the introduction of the National Credit Act in July reduced consumer demand and reduced activities in the retail sector since the second half of 2007.

Inflation: CPIX inflation increased substantially resulting from higher food prices and a steep increase in the international oil price. Driven by higher prices of domestically produced goods, year-on-year PPI inflation doubled from 2005 to 2006 and continued to accelerate to reach double-digit rates in 2007.

Current account: global economic growth decreased significantly since the fourth quarter of 2007 mainly because of turbulence in international financial markets. The deficit on the current account continued to increase to a new record of R158billion in the third quarter or $-8,1 \%$ of GDP well above the international norm of $-3 \%$. Despite strong growth in fixed capital expenditure in South Africa, the trade deficit declined substantially in the last quarter relative to the third quarter. Exports increased substantially in the last quarter mainly due to capacity building in the Chinese economy which more than offset the increased imports of South Africa during 2007.

\subsubsection{Economic developments 2008 (SARB, 2009)}

Growth: real economic activity declined mainly because of the deterioration in the global economy. Relative stable growth was recorded in the primary sector, but a significant slowdown was recorded in the secondary and tertiary sectors. The economic activity was also hampered in the first quarter because of the Eskom electricity crisis.

Inflation: CPIX inflation continued to increase to a peak of $13,6 \%$ in August. PPI inflation also continued to increase and reached a peak of $19,1 \%$ in August. This was due to tremendous increases in the prices of commodities, products of petroleum and coal, manufactured food as well as chemical products. The scenario changed completely in the second half of the year when the world experienced a recession and commodity prices tumbled.

Current account: South Africa's balance of payments was strongly influenced by the deterioration in the world economy since the second half of 2008. The volume of exports contracted tremendously in the second half of the year, whilst the imported values contracted because of a substantial decline in the international oil price and a decline in domestic demand for imported manufactured goods.

\subsubsection{Economic developments 2009 (SARB, 2010)}

Growth: Minister Manual tabled his last budget in 2009 and continued to make forecasts regarding all three economic indicators. Early indications for the first half of the year was that the growth rate declined $-7,4 \%$ in the first quarter and $2,8 \%$ in the second quarter. South Africa moved in the first half of the year into a recession, the first time since 1992 . The sharp decline in real economic activity occurred because of a severe contraction in global activities and a consequent decline of our merchandise exports. The growth rate improved in the second half of the year, but the growth rate for the year was $-1,8 \%$.

Inflation: in February the Department of Statistics launched a new consumer inflation index and the inflation rate declined for statistical reasons. Domestic producer and consumer price inflation began to decrease since the spring of 2008 in step with global price developments. Administered prices continued to prevent a substantial decrease in prices in 2009. Headline inflation that remained for 30 months above the target range, declined since October to within the target range.

Current account: the continued deterioration of global economic activities caused a contraction in trade volumes and negative current account balances of almost all emerging countries. The volume of merchandise exports declined, but the relatively low level of international crude oil prices and the appreciation of the Rand, continued to weigh down the negative effects experienced regarding declining exports up to the winter period of the year.

\section{Conclusion}

This research critically analysed the forecasting accuracy of Minister Manuel for the period whilst he was Minister of National Treasury. Three macroeconomic indicators were analysed, namely economic growth, inflation and the balance of payments. The forecasting process was discussed to explain the complex nature and the different methods that are available for forecasters. Although various models are available, it is a fact that a hundred percent accurate forecast is 
the exception rather than the rule.

In conclusion, to say that a forecasted value is accurate does not mean the forecasted value is exactly equal to the realized figure. The annual prediction of the Minister was compared to the first available data from SARB and the Department of Statistics. Forecasters in South Africa have no option but to use the data available to them when they make their forecasts. It is a lost case to wait for final statistics because the data in South Africa are revised on a regular basis which can be released more than a year later.

The forecasts for economic growth were very good. The most conservative forecast can be observed for 1998 and 2009. Firm policy measures to defend the Rand during the Asian crisis caused a decline in the actual growth rate. National Treasury applied proper counter cyclical fiscal policy in 2008 and 2009 to mitigate the negative impact of the biggest recession since the great depression of the 1930s.

The forecasts for inflation were also very good. Two conservative forecasts can be observed for 2002 and 2008. The main reason for the very high inflation in 2002 was the sharp depreciation of the Rand since the last months of 2001. The main reason for the high inflation in 2008 was the big increases in the prices of commodities in the world as well as the international oil price and food, mainly because of the Far East effect.

The forecasts for the current account balance were the least accurate. Conservative forecasts can be observed for the years 2004 - 2007. The directions of changes in the current account variable were however correct except for 2002.

This research confirms that the previous Minister of Finance's forecasts were relative accurate. It is only in years that an international crisis occurred that his forecasted values deviated the most relative to the actual values. Although the Minister was wrong regarding the actual values, his direction of changes was correct.

\section{Addendum}

All parties interested in economic events that do not have the time, skills or money to do their own forecasting, can rely on the judgment of the team of economists at the Department of National Treasury. The forecast results of the new Minister of Finance that succeeded Minister Manuel are indicated in Table 6.1 and should also be analyzed with a degree of confidence regarding accuracy and reliability.

Table 6.1: Actual versus forecasted GDP, Inflation and Current Account

\begin{tabular}{|c|c|c|c|c|c|c|}
\hline & \multicolumn{2}{|c|}{ GDP } & \multicolumn{2}{c|}{ Inflation } & \multicolumn{2}{c|}{ Current Account } \\
\hline & Forecast & Actual & Forecast & Actual & Forecast & Actual \\
\hline 2010 & 2.3 & 2.8 & 5.8 & 4.3 & -4.9 & -2.8 \\
\hline 2011 & 3.4 & 3.1 & 4.9 & 5.0 & -4.2 & -3.3 \\
\hline 2012 & 2.7 & 2.5 & 6.2 & 5.6 & -4.3 & -6.3 \\
\hline 2013 & 2.7 & 1.9 & 5.6 & 5.7 & -6.2 & -5.8 \\
\hline
\end{tabular}

Source: SARB (2014)

\section{References}

Armstrong, J. S. (1985). Long-range forecasting: From crystal ball to computer. (2nd ed.). New York: John Wiley \& Sons.

Armstrong, J. S., \& Collopy, F. (1998). Integration of statistical methods and judgment for time series forecasting: principles from empirical research. New York: Wiley.

Black, P., Hartzenberg, T., \& Standish, B. (1997). Economics, Principles and Practice. (2nd ed.). London: Financial Times Management.

Burda, M., \& Wyplosz, C. (2009). Macroeeconomics, A European Text. (5th ed.). New York: Oxford University Press Inc.

Butler, W. F., \& Kavesh, R. A. (1974). Judgmental forecasting of the gross national product. In W. F. Butler, R. A. Kavesh, \& R. B. Platt (Eds.), Methods and techniques of business forecasting. New Jersey: Prentice Hall.

Carnot, N., Koen, V., \& Bruno, T. (2005). Economic Forecasting. New York: Palgrave Macmillan.

Clements, M. P., \& Hendry, D. F. (2002). A companion to economic forecasting. Massachusetts: Blackwell Publishers.

Dornbusch, R., \& Fisher, S. (1987). Macroeconomics. Johannesburg: Lexicon.

Dornbusch, R., Fisher, S., \& Startz, R. (2004). Macroeconomics. (3rd ed.). New York: McGraw-Hill.

Fourie, F. C., \& Burger, P. (2010) How to think and reason in Macroeconomics. (3rd ed.). Claremont: Juta \& Co.

Gordhan, P, J. (2010), National budget review of 2010. [Online] Available: http://www.treasury.gov.za/documents/nationalbudget/ nationalbudgetreview/economicpolicy\& outlook/2010 (November 30, 2013)

Gordhan, P, J. (2011), National budget review of 2011. [Online] Available: http://www.treasury.gov.za/documents/nationalbudget/ nationalbudgetreview/economicpolicy\& outlook/2011 (November 30, 2013) 
Gordhan, P, J. (2012), National budget review of 2012. [Online] Available: http://www.treasury.gov.za/documents/nationalbudget/ nationalbudgetreview/economicpolicy\& outlook/2012 (November 30, 2013)

Gordhan, P, J. (2013), National budget review of 2013. [Online] Available: http://www.treasury.gov.za/documents/nationalbudget/ nationalbudgetreview/economicpolicy\& outlook/2013 (November 30, 2013)

Green, P. (2008). Choice, not Fate: The Life and Times of Trevor Manual. Johannesburg: Penguin Group.

Janse Van Rensburg, J., McConnell, C., \& Brue, S. Economics, Southern African Edition. London: McGraw-Hill.

Kennedy, P. (1985). A guide to econometrics. Oxford: Basil Blackwell.

Koutsiyiannis, A. (1977). Theory of econometrics. (2nd ed.). New Jersey: Barnes \& Noble Books.

Lanchester, G. A., \& Lomas, R. A. (1985). Forecasting for sales and materials management. Houndmills: Macmillan Publishers.

Levenbach, H., \& Cleary, J. P. (1984). The modern forecaster: the forecasting process through data analysis. California: Lifetime learning publications.

Manuel, T, A. (1997), National budget review of 1997. [Online] Available: http://www.treasury.gov.za/documents/nationalbudget/ nationalbudgetreview/economicpolicy\& outlook/1997 (November 15, 2013)

Manuel, T, A. (1998), National budget review of 1998. [Online] Available: http://www.treasury.gov.za/documents/nationalbudget Inationalbudgetreview/economicpolicy\& outlook/1998 (November 15, 2013)

Manuel, T, A. (1999), National budget review of 1999. [Online] Available: http://www.treasury.gov.za/documents/nationalbudget/ nationalbudgetreview/economicpolicy\& outlook/1999 (November 15, 2013)

Manuel, T, A. (2000), National budget review of 2000. [Online] Available: http://www.treasury.gov.za/documents/nationalbudget/ nationalbudgetreview/economicpolicy\& outlook/2000 (November 15, 2013)

Manuel, T, A. (2001), National budget review of 2001. [Online] Available: http://www.treasury.gov.za/documents/nationalbudget/ nationalbudgetreview/economicpolicy\& outlook/2001 (November 20, 2013)

Manuel, T, A. (2002), National budget review of 2002. [Online] Available: http://www.treasury.gov.za/documents/nationalbudget/ nationalbudgetreview/economicpolicy\& outlook/2002 (November 20, 2013)

Manuel, T, A. (2003), National budget review of 2003. [Online] Available: http://www.treasury.gov.za/documents/nationalbudget/ nationalbudgetreview/economicpolicy\& outlook/2003 (November 20, 2013)

Manuel, T, A. (2004), National budget review of 2004. [Online] Available: http://www.treasury.gov.za/documents/nationalbudget/ nationalbudgetreview/economicpolicy\& outlook/2004 (November 20, 2013)

Manuel, T, A. (2005), National budget review of 2005. [Online] Available: http://www.treasury.gov.za/documents/nationalbudget/ nationalbudgetreview/economicpolicy\& outlook/2005 (November 25, 2013)

Manuel, T, A. (2006), National budget review of 2006. [Online] Available: http://www.treasury.gov.za/documents/nationalbudget/ nationalbudgetreview/economicpolicy\& outlook/2006 (November 25, 2013)

Manuel, T, A. (2007). National budget review of 2007. [Online] Available: http://www.treasury.gov.za/documents/nationalbudget/ nationalbudgetreview/economicpolicy\& outlook/2007 (November 25, 2013)

Manuel, T, A. (2008), National budget review of 2008. [Online] Available: http://www.treasury.gov.za/documents/nationalbudget/ nationalbudgetreview/economicpolicy\& outlook/2008 (November 25, 2013)

Manuel, T, A. (2009), National budget review of 2009. [Online] Available: http://www.treasury.gov.za/documents/nationalbudget/ nationalbudgetreview/economicpolicy\& outlook/2009 (November 25, 2013)

Mohr, P. (2000). Economic indicators. (Revised ed.). Pretoria: Unisa.

Mohr, P., \& Fourie, L. (2008). Economics for South African students. (4th ed.). Paarl: Van Schaik Publishers.

Passer, H. C., \& Fielder, E. R. (1974). Econometric forecasting in government. In W. F. Butler, R. A. Kavesh, \& R. B. Platt (Eds.), Methods and techniques of business forecasting. New York: Prentics Hall.

Smit, P. C., Dams, D.J., Mostert, J. W., Oosthuizen, A.G., Van der Vyfer, T. C., \& Van Gass, W. (1997). Economics, a South African Perspective. Cape Town: Juta \& Co.

South African Reserve Bank (1998). Research Department. Quarterly Bulletin, March. Pretoria.

South African Reserve Bank (1999). Research Department. Quarterly Bulletin, March. Pretoria.

South African Reserve Bank (2000). Research Department. Quarterly Bulletin, March. Pretoria.

South African Reserve Bank (2001). Research Department. Quarterly Bulletin, March. Pretoria.

South African Reserve Bank (2002). Research Department. Quarterly Bulletin, March. Pretoria.

South African Reserve Bank (2003). Research Department. Quarterly Bulletin, March. Pretoria.

South African Reserve Bank (2004). Research Department. Quarterly Bulletin, March. Pretoria.

South African Reserve Bank (2005). Research Department. Quarterly Bulletin, March. Pretoria.

South African Reserve Bank (2006). Research Department. Quarterly Bulletin, March. Pretoria.

South African Reserve Bank (2007). Research Department. Quarterly Bulletin, March. Pretoria.

South African Reserve Bank (2008). Research Department. Quarterly Bulletin, March. Pretoria.

South African Reserve Bank (2009). Research Department. Quarterly Bulletin, March. Pretoria.

South African Reserve Bank (2010). Research Department. Quarterly Bulletin, March. Pretoria.

South African Reserve Bank (2013). Research Department. Quarterly Bulletin, March. Pretoria.

Wilson, J. H., \& Keating, B. (1994). Business forecasting. (2nd ed.). Boston: Mcgraw Hill.

Wright, W., \& Goodwin, P. (1986). Forecasting with Judgment. Chichester: Wiley \& Sons.

Young, M. (1968). Forecasting and the social science. London: Heinemann. 
Zarnowitz, V. (1974). How accurate have forecasts been? In W. F. Butler, R. A. Kavesh, \& R. B. Platt (Eds.), Methods and techniques of business forecasting. New York: Prentics Hall. 